\title{
Daphnane Diterpenoids from Trigonostemon lii and Inhibition Activities Against HIV-1
}

\author{
Cheng-Jian Tan ${ }^{1,3} \cdot$ Shi-Fei $\mathrm{Li}^{1,4} \cdot$ Ning Huang $^{2,5} \cdot$ Yu Zhang $^{1} \cdot$ Ying-Tong $\mathrm{Di}^{1} \cdot$ Yong-Tang Zheng $^{2} \cdot$ Xiao-Jiang Hao $^{1}$
}

Received: 3 December 2019 / Accepted: 14 January 2020 / Published online: 11 February 2020

(c) The Author(s) 2020

\begin{abstract}
Natural products are the important source for the discovery of more potent anti-HIV agents. In this study, six daphnane diterpenoids including three unreported structures were isolated from Trigonostemon lii, which showed significant activities against HIV-1 strains replication in the nanomolar/picomolar range. Meanwhile, these diterpenoids significantly inhibited the fusion of H9/HIV-1 IIIB cells with uninfected C8166 cells, with the $\mathrm{EC}_{50 \mathrm{~s}}$ from 1.06 to $8.73 \mathrm{ng} / \mathrm{mL}$, and did not show any inhibition activities against HIV-1 reverse transcriptase. Moreover, all of the diterpenoids shows significant inhibitions against T20-resistan HIV-1 strains, PNL4-3gp41(36G)V38E, N42S and pNL4-3gp41(36G)V38A, N42T. The results revealed that the six diterpenoids could be a new type of potential lead candidate as an HIV entry inhibitor, particularly for those infected by T20-resistant variants.
\end{abstract}

\section{Graphic Abstract}
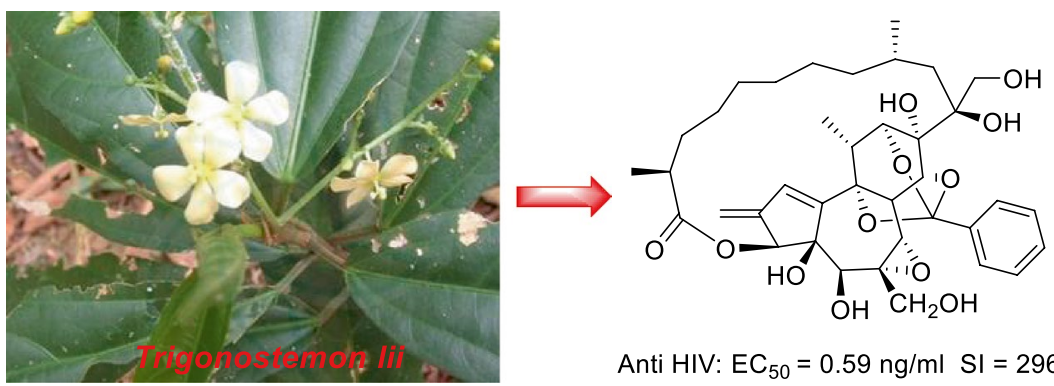

Anti HIV: $\mathrm{EC}_{50}=0.59 \mathrm{ng} / \mathrm{ml} \mathrm{SI}=29610$

Keywords Trigonostemon lii $\cdot$ Daphnane diterpenoid $\cdot$ Trigonolactone $\cdot$ Anti-HIV

We dedicate this paper to Prof. Sun Han-Dong on the occasion of his 80th birthday.

Cheng-Jian Tan, Shi-Fei Li and Ning Huang contributed equally to this work.

\section{Electronic supplementary material The online version of this} article (https://doi.org/10.1007/s13659-020-00231-7) contains supplementary material, which is available to authorized users.

Yong-Tang Zheng

zhengyt@mail.kiz.ac.cn

Xiao-Jiang Hao

haoxj@mail.kib.ac.cn

Extended author information available on the last page of the article

\section{Introduction}

According to the latest report on the global AIDS epidemic, infections with the human immunodeficiency virus 1 (HIV1) remain a global threat to public health [1]. Drug treatment for controlling viral loads and for prolonging patients' lives is the main therapy for HIV-1 infections. Highly active anti-retroviral therapy now has shown significant synergistic effects on prolonging the lifetime and decreasing the mortality of patients, the issues such as toxicity, viral reservoirs and drug resistance have led to a subsequent crisis in the management of HIV/AIDS patients [2]. The potent drugs may fail at a later stage. In the light of these considerations, new classes of drugs against HIV are in urgent need to develop. 
The process of HIV-1 entry into host cells considerable potential for therapeutic intervention, with viral entry proceeding through multiple sequential steps involving attachment, coreceptor blinding, and fusion [3]. The discovery and characterization of new anti-HIV agents of those steps to be the host remain priority.

Natural products have served as the important leads for the discovery of more potent anti-HIV agents $[4,5]$. However, very few natural products were discovered as having anti-HIV-1 potential in the nanomolar/picomolar range [4, 6]. Here, we reported six daphnane diterpenoids (compounds 1-6) including three unreported ones [trigonolactones B (1), D (2) and E (3)] with significant anti-HIV-1 activity from Trigonostemon lii [7] (Fig. 1). These compounds not only exhibited strong inhibition on HIV replication with $\mathrm{EC}_{50}$ values of $0.59-8.22 \mathrm{ng} / \mathrm{mL}$ and SI values of 1811-29,610, but also displayed significantly inhibited the fusion of H9/HIV1IIIB cells with uninfected $\mathrm{C} 8166$ cells with $\mathrm{EC}_{50}$ values of $1.06-8.73 \mathrm{ng} / \mathrm{mL}$, while did not show any inhibition activity against HIV-1 reverse transcriptase. More important, these compounds still displayed significant inhibitions against T20-resistant HIV-1 strains, pNL4-3gp41(36G)V38E, N42S and pNL4-3gp41(36G)V38A, N42T. The structures of these compounds were established by spectroscopic approach including 1D, 2D NMR and HRMS technology.

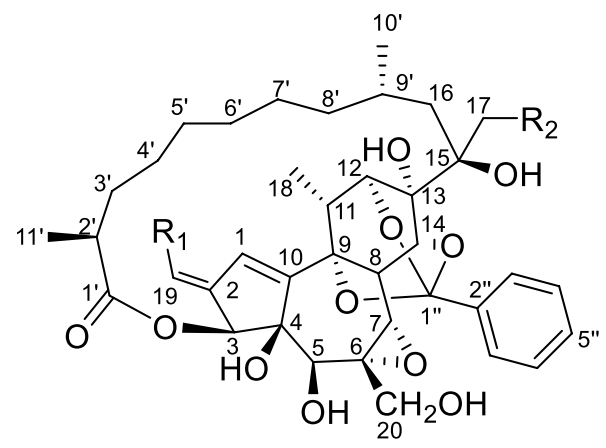

$\begin{array}{lll}\text { Trigonolactone B (1) } & \mathrm{R}_{1}=\mathrm{H} & \mathrm{R}_{2}=\mathrm{H} \\ \text { Trigonolactone D (2) } & \mathrm{R}_{1}=\mathrm{H} & \mathrm{R}_{2}= \\ \text { Trigonolactone E (3) } & \mathrm{R}_{1}=\mathrm{H} & \mathrm{R}_{2}=\mathrm{OH} \\ \text { Trigocherriolide B (4) } & \mathrm{R}_{1}=\mathrm{Cl} & \mathrm{R}_{2}=\mathrm{H} \\ \text { Trigocherriolide A (5) } & \mathrm{R}_{1}=\mathrm{Cl} & \mathrm{R}_{2}={ }^{\prime} \\ \text { Trigocheriolide E (6) } & \mathrm{R}_{1}=\mathrm{Cl} & \mathrm{R}_{2}=\mathrm{OH}\end{array}$

Fig. 1 The structures of compounds 1-6 from the Trigonostemon lii

\section{Results and Discussion}

\subsection{Structure Elucidation}

Trigonolactone B (1) was obtained as an optically active white powder, and the molecular formula was established to be $\mathrm{C}_{38} \mathrm{H}_{50} \mathrm{O}_{11}$ by HR-ESI-MS [m/z $705.3248(\mathrm{M}+\mathrm{Na})^{+}$, calcd 705.3250], requiring 14 degrees of unsaturation. The IR spectrum showed absorptions that were typical of hydroxy $\left(3442 \mathrm{~cm}^{-1}\right)$ and ester $\left(1710 \mathrm{~cm}^{-1}\right)$ functionalities. The ${ }^{1} \mathrm{H}$ NMR spectrum of $\mathbf{1}$ (Table 1 ) indicated the presence of four methyls $\left(\delta_{\mathrm{H}} 1.37(s), 1.23(d, J=6.9)\right.$, $1.04(d, J=8.0), 1.19(d, J=9.0)$ and one monosubstituted benzene ring $\left[\delta_{\mathrm{H}} 7.76(2 \mathrm{H}, m), 7.41(2 \mathrm{H}, m)\right.$ and $7.41(1 \mathrm{H}, m)]$. The ${ }^{13} \mathrm{C}$ NMR data identified 38 carbon signals, categorized as 10 quaternary carbons (one ester, three olefinics, one orthoester and five oxygenated), 15 methines, 9 methylenes and 4 methyls (Table 1). The above data suggested that compound $\mathbf{1}$ and the previously identified molecule trigocherriolide B $[8,9]$ share a similar scaffold, except that one methylene signal at $\delta_{\mathrm{H}} 5.17$ (s), 5.07 (s) replaced the C-19 methine signal at $\delta_{\mathrm{H}} 6.07$ (s) in latter. Considering the molecular weight of $\mathbf{1}$ is 34 units less than that of trigocherriolide $\mathrm{B}$, the compound should be 19-dechloro form of trigocherriolide $\mathrm{B}$. The further HMBC cross peaks from $\mathrm{H}-3$ to $\mathrm{C}-1$ and C-19, $\mathrm{H}_{2}-19$ to $\mathrm{C}-2$ and $\mathrm{C}-1$, and $\mathrm{H}-1$ to $\mathrm{C}-19$ and $\mathrm{C}-2$ located the exo-methylene at $\mathrm{C}-19$. Thus, the gross structure of trigonolactone B (1) was established as shown (Fig. 2).

The relative configuration of $\mathbf{1}$ was elucidated by the ROESY experiment and compared with known compounds. The ROESY spectrum exhibited strong correlations of the axial $\mathrm{H}-11$ to $\mathrm{H}-8$ and $\mathrm{H}-12$, orienting $\mathrm{H}-8$ and $\mathrm{H}-12$ on the $\beta$-orientation. The $\beta$-configurations of $\mathrm{H}-14, \mathrm{OH}-4$ and $\mathrm{H}-7$ were established on the correlations of $\mathrm{H}-8$ to $\mathrm{H}-7, \mathrm{H}-14$ and $\mathrm{OH}-4$, meanwhile revealed that the 9, 12, 14-orthobenzoate was $\alpha$-directed. The mutual ROESY correlations between H-3 and H-5 oriented the same $\alpha$-configuration. Thus, the structure of $\mathbf{1}$ was elucidated as shown (Fig. 3).

The molecular formula of trigonolactone D (2) was indicated to be $\mathrm{C}_{45} \mathrm{H}_{54} \mathrm{O}_{14}$ by HRESIMS $[\mathrm{m} / \mathrm{z} 841.3417$ $(\mathrm{M}+\mathrm{Na})^{+}$, calcd 841.3411]. Compared the ${ }^{1} \mathrm{H}$ and ${ }^{13} \mathrm{C}$ NMR data (Table 1) with 1, one more 1,2-disubstituted benzen ring $\left(\delta_{\mathrm{H}} 7.18(d, J=10), 7.49(t, J=10), 6.92(t\right.$, $J=10), 7.70(d d, J=1.5,10)$ and ester carbonyl signal at $\delta_{\mathrm{C}} 170.1$ were easily assigned. The HMBC correlations of $\mathrm{H}-17 \alpha\left(\delta_{\mathrm{H}} 4.78\right)$ to $\mathrm{C}-13, \mathrm{C}-15, \mathrm{C}-16$ and $\mathrm{C}-1^{\prime \prime \prime}$ confirmed compound 2 was the 17-(2-hydroxybenzoate) derivative of $\mathbf{1}$. The relative configuration of $\mathbf{2}$ were elucidated by ROESY spectroscopy and similar with $\mathbf{1}$.

The molecular formula of trigonolactone $\mathrm{E}(\mathbf{3})$ was established as $\mathrm{C}_{38} \mathrm{H}_{50} \mathrm{O}_{12}$ by HRESIME $[\mathrm{m} / \mathrm{z} 721.3194$ 
Table $1{ }^{1} \mathrm{H}$ NMR and ${ }^{13} \mathrm{C}$ NMR Data of $\mathbf{1}-\mathbf{3}$

\begin{tabular}{|c|c|c|c|c|c|c|}
\hline \multirow[t]{2}{*}{ No } & \multicolumn{2}{|l|}{1} & \multicolumn{2}{|l|}{2} & \multicolumn{2}{|l|}{3} \\
\hline & $\overline{\delta_{\mathrm{H}}{ }^{\mathrm{a}}}$ & $\delta_{\mathrm{C}}^{\mathrm{b}}$ & $\overline{\delta_{\mathrm{H}}{ }^{\mathrm{a}}}$ & $\delta_{\mathrm{C}}^{\mathrm{b}}$ & $\overline{\delta_{\mathrm{H}}{ }^{\mathrm{c}}}$ & $\delta_{\mathrm{C}}{ }^{\mathrm{d}}$ \\
\hline 1 & $6.30(1 \mathrm{H}, \mathrm{s})$ & $130.2 \mathrm{~d}$ & $6.21(1 \mathrm{H}, \mathrm{s})$ & $130.2 \mathrm{~d}$ & $6.22(1 \mathrm{H}, \mathrm{s})$ & $129.9 \mathrm{~d}$ \\
\hline 2 & & $145.6 \mathrm{~s}$ & & $145.5 \mathrm{~s}$ & & $145.7 \mathrm{~s}$ \\
\hline 3 & $5.38(1 \mathrm{H}, \mathrm{s})$ & $80.0 \mathrm{~d}$ & $5.35(1 \mathrm{H}, \mathrm{s})$ & $79.2 \mathrm{~d}$ & $5.24(1 \mathrm{H}, \mathrm{s})$ & $80.3 \mathrm{~d}$ \\
\hline 4 & & $83.5 \mathrm{~s}$ & & $83.2 \mathrm{~s}$ & & $83.3 \mathrm{~s}$ \\
\hline 5 & $3.87(1 \mathrm{H}, \mathrm{s})$ & $71.8 \mathrm{~d}$ & $3.78(1 \mathrm{H}, \mathrm{s})$ & $71.2 \mathrm{~d}$ & $3.92(1 \mathrm{H}, \mathrm{s})$ & $71.1 \mathrm{~d}$ \\
\hline 6 & & $60.0 \mathrm{~s}$ & & $60.1 \mathrm{~s}$ & & $61.0 \mathrm{~s}$ \\
\hline 7 & $3.49(1 \mathrm{H}, \mathrm{s})$ & $62.0 \mathrm{~d}$ & $3.01(1 \mathrm{H}, \mathrm{s})$ & $61.8 \mathrm{~d}$ & $3.34(1 \mathrm{H}, \mathrm{s})$ & $62.9 \mathrm{~d}$ \\
\hline 8 & $4.79(1 \mathrm{H}, \mathrm{s})$ & $34.5 \mathrm{~d}$ & $4.46(1 \mathrm{H}, \mathrm{s})$ & $34.2 \mathrm{~d}$ & $4.48(1 \mathrm{H}, \mathrm{s})$ & $34.6 \mathrm{~d}$ \\
\hline 9 & & $74.5 \mathrm{~s}$ & & $74.5 \mathrm{~s}$ & & $74.5 \mathrm{~s}$ \\
\hline 10 & & $147.5 \mathrm{~s}$ & & $147.2 \mathrm{~s}$ & & $147.6 \mathrm{~s}$ \\
\hline 11 & $2.77(1 \mathrm{H}, \mathrm{q}, 6.9)$ & $34.6 \mathrm{~d}$ & $2.68(1 \mathrm{H}, \mathrm{q}, 6.9)$ & $34.6 \mathrm{~d}$ & $2.78(1 \mathrm{H}, \mathrm{q}, 6.9)$ & $34.7 \mathrm{~d}$ \\
\hline 12 & $4.29(1 \mathrm{H}, \mathrm{s})$ & $79.7 \mathrm{~d}$ & $4.29(1 \mathrm{H}, \mathrm{s})$ & $79.2 \mathrm{~d}$ & $4.22(1 \mathrm{H}, \mathrm{s})$ & $79.5 \mathrm{~d}$ \\
\hline 13 & & $72.1 \mathrm{~s}$ & & $72.4 \mathrm{~s}$ & & $73.2 \mathrm{~s}$ \\
\hline 14 & $4.39(1 \mathrm{H}, \mathrm{s})$ & $79.4 \mathrm{~d}$ & $4.43(1 \mathrm{H}, \mathrm{s})$ & $79.2 \mathrm{~d}$ & $4.67(1 \mathrm{H}, \mathrm{s})$ & $79.7 \mathrm{~d}$ \\
\hline 15 & & $75.3 \mathrm{~s}$ & & $75.8 \mathrm{~s}$ & & $76.1 \mathrm{~s}$ \\
\hline $16 \alpha$ & $1.43(1 \mathrm{H}, \mathrm{m})$ & $37.9 \mathrm{t}$ & $1.87(1 \mathrm{H}, \mathrm{d}, 18.0)$ & $37.2 \mathrm{t}$ & $1.39(1 \mathrm{H}, \mathrm{m})$ & $35.9 \mathrm{t}$ \\
\hline $16 \beta$ & $1.71(1 \mathrm{H}, \mathrm{m})$ & & $1.56(1 \mathrm{H}, \mathrm{dd}, 7.5,18.0)$ & & $1.65(1 \mathrm{H}, \mathrm{m})$ & \\
\hline $17 \alpha$ & $1.37(3 \mathrm{H}, \mathrm{s})$ & $23.8 \mathrm{q}$ & $4.78(1 \mathrm{H}, \mathrm{d}, 14.5)$ & $67.8 \mathrm{t}$ & $3.90(1 \mathrm{H}, \mathrm{d}, 10.0)$ & $65.2 \mathrm{t}$ \\
\hline $17 \beta$ & & & $4.54(1 \mathrm{H}, \mathrm{d}, 14.5)$ & & $3.61(1 \mathrm{H}, \mathrm{d}, 10.0)$ & \\
\hline 18 & $1.23(3 \mathrm{H}, \mathrm{d}, 6.9)$ & $13.9 \mathrm{q}$ & $1.23(3 \mathrm{H}, \mathrm{d}, 6.9)$ & $13.9 \mathrm{q}$ & $1.20(3 \mathrm{H}, \mathrm{d}, 6.9)$ & $13.7 \mathrm{q}$ \\
\hline 19 & $\begin{array}{l}5.17(1 \mathrm{H}, \mathrm{s}) \\
5.07(1 \mathrm{H}, \mathrm{s})\end{array}$ & $111.2 \mathrm{t}$ & $\begin{array}{l}5.11(1 \mathrm{H}, \mathrm{s}) \\
5.01(1 \mathrm{H}, \mathrm{s})\end{array}$ & $111.3 \mathrm{t}$ & $\begin{array}{l}5.13(1 \mathrm{H}, \mathrm{s}) \\
5.06(1 \mathrm{H}, \mathrm{s})\end{array}$ & $110.0 \mathrm{t}$ \\
\hline 20 & $\begin{array}{l}3.91(1 \mathrm{H}, \mathrm{d}, 15.0) \\
3.75(1 \mathrm{H}, \mathrm{d}, 15.0)\end{array}$ & $62.4 \mathrm{t}$ & $\begin{array}{l}3.56(1 \mathrm{H}, \mathrm{br} \mathrm{s}) \\
3.42(1 \mathrm{H}, \mathrm{br} \mathrm{s})\end{array}$ & $62.8 \mathrm{t}$ & $3.74(2 \mathrm{H}, \mathrm{m})$ & $65.1 \mathrm{t}$ \\
\hline $1^{\prime}$ & & $179.7 \mathrm{~s}$ & & $179.2 \mathrm{~s}$ & & 178.5 \\
\hline $2^{\prime}$ & $2.35(1 \mathrm{H}, \mathrm{m})$ & $42.8 \mathrm{~d}$ & $2.31(1 \mathrm{H}, \mathrm{m})$ & $42.5 \mathrm{~d}$ & $2.41(1 \mathrm{H}, \mathrm{m})$ & $42.0 \mathrm{~d}$ \\
\hline $\begin{array}{l}3^{\prime} \alpha \\
3^{\prime} \beta\end{array}$ & $\begin{array}{l}1.69(1 \mathrm{H}, \mathrm{m}) \\
1.30(1 \mathrm{H}, \mathrm{m})\end{array}$ & $35.1 \mathrm{t}$ & $\begin{array}{l}1.67(1 \mathrm{H}, \mathrm{m}) \\
1.28(1 \mathrm{H}, \mathrm{m})\end{array}$ & $34.9 \mathrm{t}$ & $\begin{array}{l}1.67(1 \mathrm{H}, \mathrm{m}) \\
1.32(1 \mathrm{H}, \mathrm{m})\end{array}$ & $34.9 \mathrm{t}$ \\
\hline $\begin{array}{l}4^{\prime} \alpha \\
4^{\prime} \beta\end{array}$ & $\begin{array}{l}1.30(1 \mathrm{H}, \mathrm{m}) \\
1.06(1 \mathrm{H}, \mathrm{m})\end{array}$ & $31.6 \mathrm{t}$ & $\begin{array}{l}1.30(1 \mathrm{H}, \mathrm{m}) \\
1.11(1 \mathrm{H}, \mathrm{m})\end{array}$ & $31.3 \mathrm{t}$ & $\begin{array}{l}1.29(1 \mathrm{H}, \mathrm{m}) \\
1.10(1 \mathrm{H}, \mathrm{m})\end{array}$ & $31.1 \mathrm{t}$ \\
\hline $5^{\prime}$ & $1.30(2 \mathrm{H}, \mathrm{m})$ & $27.2 \mathrm{t}$ & $1.30(2 \mathrm{H}, \mathrm{m})$ & $27.2 \mathrm{t}$ & $1.26(2 \mathrm{H}, \mathrm{m})$ & $26.8 \mathrm{t}$ \\
\hline $6^{\prime}$ & $1.43(2 \mathrm{H}, \mathrm{m})$ & $28.3 \mathrm{t}$ & $1.38(2 \mathrm{H}, \mathrm{m})$ & 28.3 & $1.41(2 \mathrm{H}, \mathrm{m})$ & 28.6 \\
\hline $\begin{array}{l}7^{\prime} \alpha \\
7^{\prime} \beta\end{array}$ & $\begin{array}{l}1.48(1 \mathrm{H}, \mathrm{m}) \\
1.15(1 \mathrm{H}, \mathrm{m})\end{array}$ & $27.8 \mathrm{t}$ & $\begin{array}{l}1.52(1 \mathrm{H}, \mathrm{m}) \\
1.14(1 \mathrm{H}, \mathrm{m})\end{array}$ & $28.2 \mathrm{t}$ & $\begin{array}{l}1.47(1 \mathrm{H}, \mathrm{m}) \\
1.18(1 \mathrm{H}, \mathrm{m})\end{array}$ & $27.6 \mathrm{t}$ \\
\hline $\begin{array}{l}8^{\prime} \alpha \\
8^{\prime} \beta\end{array}$ & $\begin{array}{l}1.21(1 \mathrm{H}, \mathrm{m}) \\
1.36(1 \mathrm{H}, \mathrm{m})\end{array}$ & $37.5 \mathrm{t}$ & $\begin{array}{l}1.40(1 \mathrm{H}, \mathrm{m}) \\
1.29(1 \mathrm{H}, \mathrm{m})\end{array}$ & $37.9 \mathrm{t}$ & $\begin{array}{l}1.19(1 \mathrm{H}, \mathrm{m}) \\
1.30(1 \mathrm{H}, \mathrm{m})\end{array}$ & $38.2 \mathrm{t}$ \\
\hline $9^{\prime}$ & $1.55(1 \mathrm{H}, \mathrm{m})$ & $24.9 \mathrm{~d}$ & $1.77(1 \mathrm{H}, \mathrm{m})$ & $25.4 \mathrm{~d}$ & $1.60(1 \mathrm{H}, \mathrm{m})$ & $25.1 \mathrm{~d}$ \\
\hline $10^{\prime}$ & $1.04(3 \mathrm{H}, \mathrm{d}, 8.0)$ & $25.0 \mathrm{q}$ & $1.07(3 \mathrm{H}, \mathrm{d}, 7.5)$ & $24.1 \mathrm{q}$ & $0.95(3 \mathrm{H}, \mathrm{d}, 6.5)$ & $24.3 \mathrm{q}$ \\
\hline $11^{\prime}$ & $1.19(3 \mathrm{H}, \mathrm{d}, 9.0)$ & $18.8 \mathrm{q}$ & $1.18(3 \mathrm{H}, \mathrm{d}, 8.5)$ & $18.8 \mathrm{q}$ & $1.16(3 \mathrm{H}, \mathrm{d}, 7.0)$ & $18.6 \mathrm{q}$ \\
\hline $1^{\prime \prime}$ & & $108.4 \mathrm{~s}$ & & $108.4 \mathrm{~s}$ & & $108.4 \mathrm{~s}$ \\
\hline $2^{\prime \prime}$ & & $138.5 \mathrm{~s}$ & & $138.4 \mathrm{~s}$ & & $138.4 \mathrm{~s}$ \\
\hline 3"/7" & $7.76(2 \mathrm{H}, \mathrm{m})$ & $125.2 \mathrm{~d}$ & $7.76(1 \mathrm{H}, \mathrm{m})$ & $125.2 \mathrm{~d}$ & $7.71(2 \mathrm{H}, \mathrm{m})$ & $125.2 \mathrm{~d}$ \\
\hline 4"/6" & $7.41(2 \mathrm{H}, \mathrm{m})$ & $128.2 \mathrm{~d}$ & $7.43(1 \mathrm{H}, \mathrm{m})$ & $128.2 \mathrm{~d}$ & $7.36(2 \mathrm{H}, \mathrm{m})$ & $128.0 \mathrm{~d}$ \\
\hline $5^{\prime \prime}$ & $7.41(1 \mathrm{H}, \mathrm{m})$ & $129.5 \mathrm{~d}$ & $7.41(1 \mathrm{H}, \mathrm{m})$ & $129.5 \mathrm{~d}$ & $7.36(1 \mathrm{H}, \mathrm{m})$ & $129.4 \mathrm{~d}$ \\
\hline $1^{\prime \prime \prime}$ & & & & $170.1 \mathrm{~s}$ & & \\
\hline $2^{\prime \prime \prime}$ & & & & $112.2 \mathrm{~s}$ & & \\
\hline $3^{\prime \prime \prime}$ & & & & $161.8 \mathrm{~s}$ & & \\
\hline $4^{\prime \prime \prime}$ & & & $7.18(1 \mathrm{H}, \mathrm{d}, 10.0)$ & $118.2 \mathrm{~d}$ & & \\
\hline $5^{\prime \prime \prime}$ & & & $7.49(1 \mathrm{H}, \mathrm{t}, 10.0)$ & $135.9 \mathrm{~d}$ & & \\
\hline $6^{\prime \prime \prime}$ & & & $6.92(1 \mathrm{H}, \mathrm{t}, 10.0)$ & $118.9 \mathrm{~d}$ & & \\
\hline
\end{tabular}


Table 1 (continued)

\begin{tabular}{|c|c|c|c|c|c|c|}
\hline \multirow[t]{2}{*}{ No } & \multicolumn{2}{|l|}{1} & \multicolumn{2}{|l|}{2} & \multicolumn{2}{|l|}{3} \\
\hline & $\delta_{\mathrm{H}}{ }^{\mathrm{a}}$ & $\delta_{\mathrm{C}}^{\mathrm{b}}$ & $\delta_{\mathrm{H}}{ }^{\mathrm{a}}$ & $\delta_{\mathrm{C}}^{\mathrm{b}}$ & $\delta_{\mathrm{H}}{ }^{\mathrm{c}}$ & $\delta_{\mathrm{C}}^{\mathrm{d}}$ \\
\hline $7^{\prime \prime \prime}$ & & & $7.70(1 \mathrm{H}, \mathrm{d}, 10.0)$ & $129.4 \mathrm{~d}$ & & \\
\hline $4-\mathrm{OH}$ & $3.67(1 \mathrm{H}, \mathrm{s})$ & & & & & \\
\hline $13-\mathrm{OH}$ & $3.83(1 \mathrm{H}, \mathrm{s})$ & & $3.94(1 \mathrm{H}, \mathrm{s})$ & & $4.05(1 \mathrm{H}, \mathrm{s})$ & \\
\hline $15-\mathrm{OH}$ & & & & & $3.40(1 \mathrm{H}, \mathrm{s})$ & \\
\hline $3^{\prime \prime \prime}-\mathrm{OH}$ & & & $10.70(1 \mathrm{H}, \mathrm{s})$ & & & \\
\hline
\end{tabular}

${ }^{\text {a }}$ Measured in $\mathrm{CDCl}_{3}$ at $400 \mathrm{MHz}$

${ }^{b}$ Measured in $\mathrm{CDCl}_{3}$ at $100 \mathrm{MHz}$

${ }^{\mathrm{c}}$ Measured in $\mathrm{CDCl}_{3}$ at $500 \mathrm{MHz}$

${ }^{\mathrm{d}}$ Measured in $\mathrm{CDCl}_{3}$ at $125 \mathrm{MHz}$

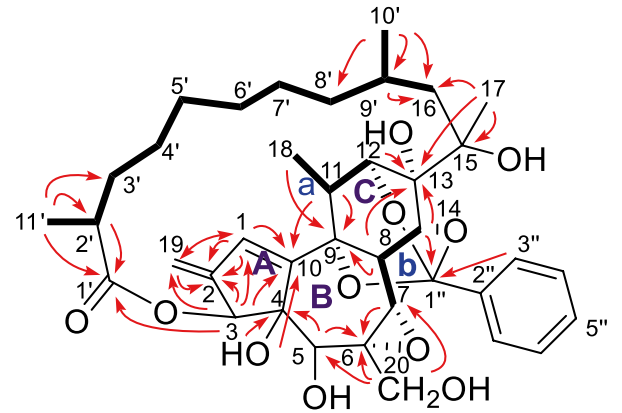

Fig. 2 Partial fragments (a-c), ${ }^{1} \mathrm{H},{ }^{1} \mathrm{H}$ COSY ( $)$ and key HMBC $(\rightarrow)$ of 1

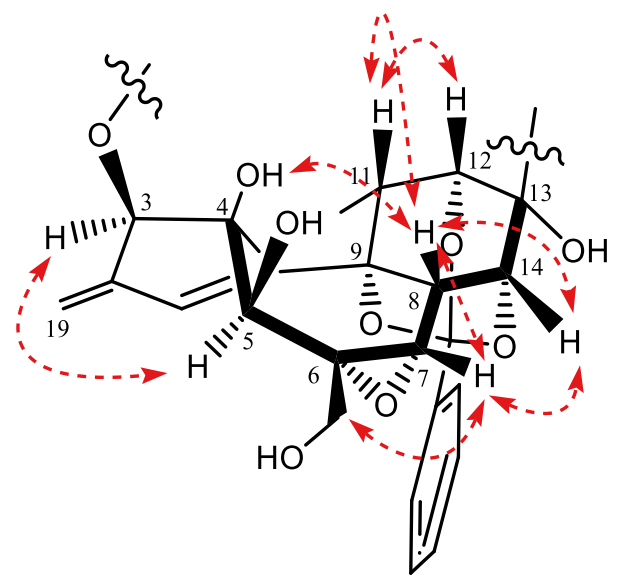

Fig. 3 Key ROESY (

$(\mathrm{M}+\mathrm{Na})^{+}$, calcd 721.3200], which displayed one more oxygen atom than that of 1. 1D and 2D NMR experiments confirmed that trigonolactone F (3) was the 17-hydroxymethy form of 1 . All other homonuclear (COSY and NOESY) and heteronuclear (HSQC and HMBC) correlations observed for $\mathbf{3}$ are like those of compound $\mathbf{1}$, thus defining its planar structure and stereochemistry as depicted in Fig. 1.

Compounds 4, 5 and 6 were identified by analysis of their spectroscopic data and comparison with literature data as trigocherriolides B and A, and trigocheriolide E [8-10], respectively.

\subsection{Anti-HIV-1 Activities}

Compounds 1-6 possessed low cytotoxicity to C8166 with $\mathrm{CC}_{50}$ were $16.47,8.49,17.47,14.89,15.52,18.29 \mu \mathrm{g} / \mathrm{mL}$ and the compounds blocked $50 \%$ of the syncytia formation induced by HIV-1 ${ }_{\text {IIIB }}$ at 1.06, 1.90, 0.59, 8.22, 2.87 and $1.50 \mathrm{ng} / \mathrm{mL}$ (Fig. 4a) (for positive controls, $\mathrm{EC}_{50}$ of AZT and T20 were 5.08 and $97.25 \mathrm{ng} / \mathrm{mL}$ ).

T20 is the only FDA-approved first-generation HIV fusion inhibitor, which is being used for treatment of HIV/AIDS patients who have failed to respond to current antiretroviral drugs. Unfortunately, many patients are now failing to respond to enfuvirtide because it rapidly induces drug resistance in vitro and in vivo [11-13]. Thus, the inhibition assay of microtiter syncytium formation of the two T20-resistant HIV-1 strains, pNL4-3gp41(36G)V38E,N42S and pNL43gp41(36G)V38A,N42T in C8166 cells, were used to evaluate anti-HIV activity, respectively. All of the compounds showed significant inhibitoies with $\mathrm{EC}_{50} \mathrm{~s}$ of 3.30, 2.72, 4.43, 2.97, 2.88 and $3.74 \mathrm{ng} / \mathrm{mL}$ for the former (Fig. 5a), and $\mathrm{EC}_{50} \mathrm{~s}$ of 2.60, 5.83, 3.19,1.85, 3.43 and $3.81 \mathrm{ng} / \mathrm{mL}$ for the later (Fig. $5 \mathrm{~b})\left(\mathrm{EC}_{50}\right.$ of $\left.\mathrm{T} 20>1000 \mathrm{ng} / \mathrm{mL}\right)$.

\subsection{Mechanisms of Action}

To address the action mechanisms, further experiments were carried out. HIV reverse transcriptase (RT) plays a very important role in the HIV replication, so the anti-HIV-1 RT activities of 1-6 were evaluated. The results demonstrated 

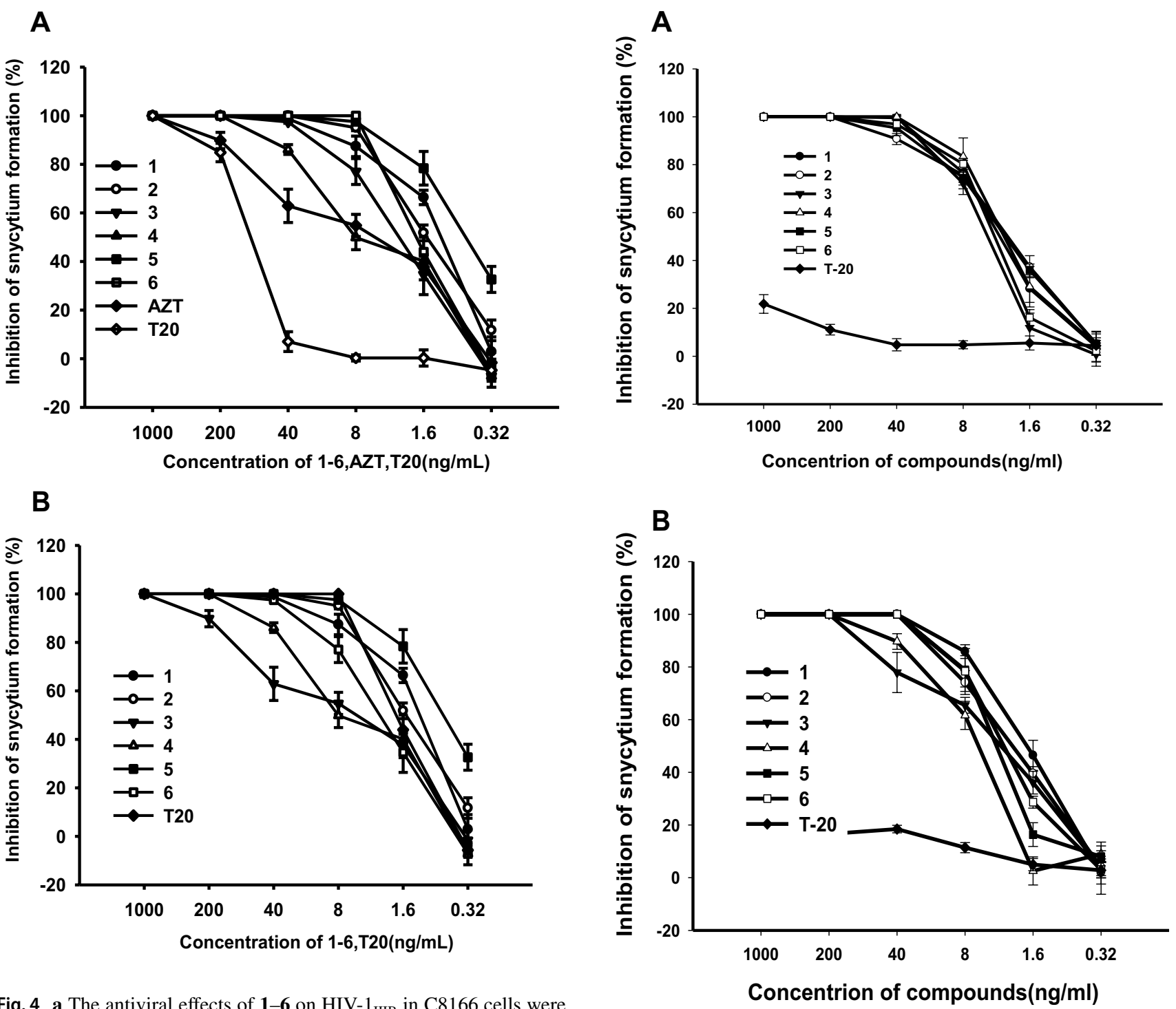

Fig. 4 a The antiviral effects of $\mathbf{1 - 6}$ on HIV $-1_{\text {IIIB }}$ in C8166 cells were assessed by syncytium formation; inhibitory activities of FuCS-1 on blocking fusion. b Inhibitory effect on cell-to-cell fusion between normal C8166 cells and HIV-1 $1_{\text {IIIB }}$ infected $\mathrm{H} 9$ cells were measured by counting the syncytia formation. Data are expressed as means \pm SD

that all of them can slightly inhibited the enzymatic activity of purified recombinant HIV-1 RT with the $\mathrm{EC}_{50} \mathrm{~s}$ of $>300$, 49.3, > 300, 199.3, 267.4 and $191.4 \mu \mathrm{g} / \mathrm{mL}$, which implied the compounds were not HIV RT inhibitor. In co-cultivation assay, compounds 1-6 effectively inhibited the fusion of $\mathrm{H} 9$ / HIV- $1_{\text {IIIB }}$ cells with uninfected C8166 cells, with $\mathrm{EC}_{50}$ values of $2.25,4.62,1.85,8.73,1.06$ and $1.76 \mathrm{ng} / \mathrm{mL}$ (as the positive control, $\mathrm{EC}_{50}$ of T20 was $9.77 \mathrm{ng} / \mathrm{mL}$ ), respectively (Fig. 4b), and when concentrations were $40 \mathrm{ng} / \mathrm{mL}$, they inhibited about $90 \%$ of syncytia formation.

To further address action mechanisms of 1-6, more experiments were carried out. In co-cultivation assay, those compounds effectively inhibited the fusion of $\mathrm{H} 9 / \mathrm{HIV}-1_{\text {IIIB }}$ cells with uninfected C8166 cells but in RT study, it was

Fig. 5 a The antiviral effects of 1-6 on pNL4-3gp41(36G) V38E,N42S in C8166 cells were assessed by syncytium formation. b The antiviral effects of 1-6 on pNL4-3gp41(36G)V38A,N42T in $\mathrm{C} 8166$ cells were assessed by syncytium formation. Data are expressed as means $\pm \mathrm{SD}$

found that they can't inhibit HIV-1 RT activity at concentration as high as $300 \mu \mathrm{g} / \mathrm{mL}$. These data supported that those compounds interfered HIV entry target cells possible.

Trigonothyrins A, B, C, D, F and G were tested for inhibitory activity against HIV-1 using the same method mentioned above $[14,15]$. Only trigonothyrins $\mathrm{C}$ and $\mathrm{F}$ showed modest anti-HIV-1 activitise with $\mathrm{EC}_{50} \mathrm{~s}$ of 2.19 and $0.13 \mu \mathrm{g} /$ $\mathrm{mL}$, and TI value of $>91.3$ and 75.1 [14]. Analysis of those structures implied the macrolactone moiety and conjugative A ring appeared to be contributed for much higher antiviral activity. Compounds 19-Chlorine substituted 4, 5 and 6 was less active than 1, 2 and $\mathbf{3}$ respectively, indicating that 
the substitution pattern is not good for the activity. When 2-hydroxyl group were introduced at C-17, the bioactivity increased significantly, indicating the substitution at C-17 contribute to the improvement of inhibitory activity.

We found compounds 1-6 possesses low cytotoxicities to C8166 and exhibited potent anti-HIV activities. It not only inhibited replication of HIV-1 laboratory strains $\left(\mathrm{HIV}-1_{\text {IIIB }}\right.$ ), but also inhibited T20-resistant strains (pNL4- $3_{\text {gp } 41(36 \mathrm{G}) \mathrm{V} 38 \mathrm{E}, \mathrm{N} 42 \mathrm{~S}}$ and pNL4-3 ${ }_{\mathrm{gp} 41(36 \mathrm{G}) \mathrm{V} 38 \mathrm{~A}, \mathrm{~N} 42 \mathrm{~T}}$ ) that those compounds showed strong inhibitory activities against all T20-resistant strains with $\mathrm{EC}_{50}$ values about $10 \mathrm{ng} / \mathrm{mL}$. It was interesting that compounds $\mathbf{1}-\mathbf{6}$ were effective in these $\mathrm{T} 20$-resistant strains and the $\mathrm{EC}_{50} \mathrm{~s}$ were similar in HIV-1IIIB. This result implied that FuSC-1 inhibit HIV with the mechanism different to HIV fusion inhibitor T20 and suggest that this class of compound can be further developed as an alternative entry inhibitor for treatment of patients with HIV-1/AIDS, those infected with T20-resistant variants.

\section{Experimental Section}

\subsection{General Experimental Procedures}

Optical rotation was carried out on a Perkin-Elmer model 241 polarimeter. IR spectra were measured in a Bio-Rad FTS-135 spectrometer with $\mathrm{KBr}$ pellets, whereas UV data were measured using a UV-210A spectrometer. Electrospary ionization-mass spectrometry (ESI-MS) and high-resolution (HR) ESI-MS were recorded with an APIQSTAR Pulsar 1 spectrometer (Advanced Biomics, Los Angeles). The 1D and 2D NMR spectra, including COSY, ROESY, HMBC, and HSQC experiments, were acquired at room temperature using a Bruker AM-400 and DRX-500 spectrometers operating at 400 and $500 \mathrm{MHz}\left({ }^{1} \mathrm{H}\right)$ and 100 and $125 \mathrm{MHz}\left({ }^{13} \mathrm{C}\right)$, respectively, with tetramethylsilane (TMS) as an internal standard. Multiplicities were determined using the DEPT pulse sequence. Column chromatography was performed on $\mathrm{Si}$ gel H (10-40 $\mu \mathrm{m}$; Qingdao Marine Chemical Factory) and Sephadex LH-20 (40-70 $\mu \mathrm{m}$, Amersham Pharmacia Biotech AB, Uppsala, Sweden). Semi-preparative HPLC was performed on a Zorbax SB-C18 $(10 \mu \mathrm{m}$, Agilent Co. Ltd. Wilmington, DE) column (i.d. $9.4 \times 250 \mathrm{~mm}$ ), developed with $\mathrm{CH}_{3} \mathrm{OH}-\mathrm{H}_{2} \mathrm{O}$ (60:40-50:50, 30 min) (flow rate, $2.0 \mathrm{~mL} / \mathrm{min}$; detection, UV $254 \mathrm{~nm}$ ) at $35^{\circ} \mathrm{C}$. AZT, dextran sulfate (DS), T-20 were purchased from Sigma. Human polyclonal anti-HIV-1 serum was kindly donated by Dr. Hiroo Hoshino (Gunma University School of Medicine, Japan). Cell lines (C8166 and H9/HIV-1 ${ }_{\text {IIIB }}$ ) were maintained in RPMI-1640 supplemented with $10 \%$ heat-inactivated newborn calf serum (Gibco). The HIV$1_{\text {IIIB }}$ virus was obtained from MRC, AIDS Reagent Project, UK. The 50\% HIV-1 tissue culture infectious dose (TCID50) was determined and calculated by the Reed and Muench method. Virus stocks were stored in aliquots at $-70{ }^{\circ} \mathrm{C}[16]$.

\subsection{Extraction and Isolation}

The leaves and twigs of Trigonostemon lii Y. T. Chang were collected in Xishuangbanna, Yunnan Province, People's Republic of China, in November, 2008, and the plant sample was identified by Prof. Shun-Cheng Zhang of Xishuangbanna Institute of Botany, Chinese Academy of Sciences (CAS). A voucher specimen (KIB 08,110,211) was deposited at the State Key Laboratory of Phytochemistry and Plant Resources in West China, Kunming Institute of Botany, Chinese Academy of Science (CAS).

Air-dried, powdered leaves and twigs $(50.0 \mathrm{~kg})$ of Trigonostemon lii $\mathrm{Y}$. T. Chang were extracted three times with Acetone at $50{ }^{\circ} \mathrm{C}$. After removal of the solvent by evaporation, the residue was suspended in $\mathrm{H}_{2} \mathrm{O}$ and partitioned with petroleum ether. The petroleum ether $(500 \mathrm{~g})$ fraction was subjected to silica gel column chromatography with a gradient elution system of petroleum ether/acetone (100:0-30:70) to obtain eight fractions (A-H). Fraction $\mathrm{F}(80.0 \mathrm{~g})$ was separated and purified by MPLC $\left(\mathrm{MeOH}-\mathrm{H}_{2} \mathrm{O}, 85: 15\right)$ to yield six fractions (C1-C6). Subfraction $\mathrm{C} 3$ was subjected to Sephadex LH-20 column chromatography $\left(\mathrm{MeOH}-\mathrm{H}_{2} \mathrm{O}\right.$, $10: 1$ ), and then further purifying by the semi-preparative HPLC to yield compounds $\mathbf{1}(60.0 \mathrm{mg}), \mathbf{2}(20.0 \mathrm{mg}), \mathbf{3}$ $(35.0 \mathrm{mg}), \mathbf{4}(100.0 \mathrm{mg}), \mathbf{5}(25.0 \mathrm{mg})$ and $\mathbf{6}(30.0 \mathrm{mg})$. All compounds were pure and dissolved in DMSO.

Trigonolactone B (1): white powder; $[\alpha]_{\mathrm{D}}^{27}=-105.4,(c$ $\left.0.14 \mathrm{CHCl}_{3}\right) ; \mathrm{UV}\left(\mathrm{CHCl}_{3}\right) \lambda_{\max }(\log \varepsilon) 246(4.18) \mathrm{nm}$; IR (KBr) $v_{\max } 3442,2924,1710,1639$ and $1453 / \mathrm{cm}$; positive ESI-MS: $m / z$ (100): 705 (100) $[\mathrm{M}+\mathrm{Na}]^{+}$; HRESIMS: $m / z$ : $705.3248[\mathrm{M}+\mathrm{Na}]^{+}, \mathrm{C}_{38} \mathrm{H}_{50} \mathrm{O}_{11} \mathrm{Na}$ (calcd 705.3250).

Trigonolactone D (2): white powder; $[\alpha]_{\mathrm{D}}^{27}=-120.0$, (c $\left.0.63 \mathrm{CHCl}_{3}\right)$; UV $\left(\mathrm{CHCl}_{3}\right) \lambda_{\max }(\log \varepsilon) 244(4.45) \mathrm{nm}$; IR (KBr) $v_{\max } 3443,2925,1704,1678,1614,1485$ and 1461/cm; positive ESI-MS: $\mathrm{m} / z$ (100): $819(18)[\mathrm{M}+\mathrm{H}]^{+}$, $841(100)[\mathrm{M}+\mathrm{Na}]^{+}$; HRESIMS: $m / z: 841.3417[\mathrm{M}+\mathrm{Na}]^{+}$, $\mathrm{C}_{45} \mathrm{H}_{54} \mathrm{O}_{14}$ (calcd 841.3411).

Trigonolactone $\mathrm{E}(3)$ : white powder; $[\alpha]_{\mathrm{D}}^{25.1}=-107.6(c$ 0.18, $\mathrm{MeOH}) ; \mathrm{V}(\mathrm{MeOH}) \lambda_{\max }(\log \varepsilon) 206$ (4.03), 245 (4.20) nm; IR (KBr) $\nu_{\max } 3441,2932,1710,1641,1453,1331$, 1269, 1084, 1030, 888, 752, 697/cm; positive ESI-MS: $\mathrm{m} / \mathrm{z}$ (100): $721(100)[\mathrm{M}+\mathrm{Na}]^{+}$; HRESIMS: $\mathrm{m} / \mathrm{z}: 721.3194$ $[\mathrm{M}+\mathrm{Na}]^{+}, \mathrm{C}_{38} \mathrm{H}_{50} \mathrm{O}_{12} \mathrm{Na}$ (calcd 721.3200).

Trigocherriolide B (4): white powder; $[\alpha]_{\mathrm{D}}^{27}=-122.5$, (c $\left.0.20 \mathrm{CHCl}_{3}\right)$; UV $\left(\mathrm{CHCl}_{3}\right) \lambda_{\max }(\log \varepsilon) 257$ (4.24) nm; IR (KBr) $v_{\max } 3455,2931,1713$ and 1618/cm; positive ESI-MS: 
$m / z(\%): 717(100)[\mathrm{M}+\mathrm{H}]^{+} 719(35)[\mathrm{M}+2]^{+}$; HRESIMS: $m / z: 739.2846[\mathrm{M}+\mathrm{Na}]^{+} ; \mathrm{C}_{38} \mathrm{H}_{49} \mathrm{O}_{11} \mathrm{NaCl}$ (calcd 739.2861).

Trigocherriolide $\mathrm{A}(\mathbf{5})$ : white powder; $[\alpha]_{\mathrm{D}}^{27}=-126.4$, (c $\left.0.67 \mathrm{CHCl}_{3}\right) ; \mathrm{UV}\left(\mathrm{CHCl}_{3}\right) \lambda_{\max }(\log \varepsilon) 248$ (4.31) $\mathrm{nm}$; IR (KBr) $v_{\max } 3444,2925,1710,1677,1640,1615$, 1485 and 1461/cm; positive ESI-MS: $m / z$ (100): 853 (20) $[\mathrm{M}+\mathrm{H}]^{+}, 855(8)[\mathrm{M}+2+\mathrm{H}]^{+}, 875(100)[\mathrm{M}+\mathrm{Na}]^{+}, 875$ (38) $[\mathrm{M}+\mathrm{Na}]^{+}$; HRESIMS: $m / z: 875.3029[\mathrm{M}+\mathrm{Na}]^{+}$, $\mathrm{C}_{45} \mathrm{H}_{53} \mathrm{O}_{14} \mathrm{NaCl}$ (calcd 875.3021).

Trigocheriolide $\mathrm{E}(\mathbf{6})$ : white powder; $[\alpha]_{\mathrm{D}}^{24.7}=-112.8$ (c $0.16, \mathrm{MeOH}) ; \mathrm{UV}(\mathrm{MeOH}) \lambda_{\max }(\log \varepsilon) 257(4.15) \mathrm{nm}$; IR (KBr) $\nu_{\max } 3441,2932,1712,1640,1453,1333,1266$, 1084, 1029, 812, 753, 697/cm; positive ESI-MS: $\mathrm{m} / z$ (100): $755(100)[\mathrm{M}+\mathrm{Na}]^{+}, 757(42)[\mathrm{M}+2+\mathrm{Na}]^{+}$; HRESIMS: $\mathrm{m} / \mathrm{z}$ : $755.2820[\mathrm{M}+\mathrm{Na}]^{+}, \mathrm{C}_{38} \mathrm{H}_{49} \mathrm{O}_{12} \mathrm{NaCl}$ (calcd 755.2810).

\subsection{MTT-Based Cytotoxicity Assay}

Cellular toxicity of compounds was assessed by MTT method. Briefly, cells were seeded on a microtiter plate in the absence or presence of various concentrations of compounds in triplicate and incubated at $37{ }^{\circ} \mathrm{C}$ in a humid atmosphere of $5 \% \mathrm{CO}_{2}$ for 3 days. Twenty microliters of MTT reagent (5 mg/mL in PBS) was added to each well, then incubated at $37{ }^{\circ} \mathrm{C}$ for $4 \mathrm{~h}, 100 \mu \mathrm{L}$ of $50 \%$ DMF-20\% SDS was added. After the formazan was dissolved completely, the plates were read on a Bio-Tek ELx 800 ELISA reader at $595 \mathrm{~nm} / 630 \mathrm{~nm}(\mathrm{~A} 595 / 630)$. The cytotoxic concentration that caused the reduction of viable cells by $50 \%$ $\left(\mathrm{CC}_{50}\right)$ was calculated from dose-response curve [17].

\subsection{Syncytia Assay}

In the presence of $100 \mu \mathrm{L}$ various concentrations of compounds, C8166 cells $\left(4 \times 10^{5} / \mathrm{mL}\right)$ were infected with virus $\left(\mathrm{HIV}-1_{\text {IIIB }}\right)$ at a multiplicity of infection (M.O.I) of 0.06 . The final volume per well was $200 \mu \mathrm{L}$. Control assays were performed without the testing compounds in HIV-1 ${ }_{\text {IIIB }}$ infected and uninfected cultures. AZT was included as positive control. After 3 days of culture, the cytopathic effect (CPE) was measured by counting the number of syncytia (multinucleated giant cell). Percentage inhibition of syncytia formation was calculated and $50 \%$ effective concentration $\left(\mathrm{EC}_{50}\right)$ was calculated $[18,19]$.

\subsection{Co-cultivation Assay}

C8166 cells $\left(3 \times 10^{4}\right)$ co-cultured with $1 \times 10^{4}$ virus (HIV$1_{\text {IIIB }}$ ) infected $\mathrm{H} 9$ cells in the presence or absence of the compound with various concentrations at $37{ }^{\circ} \mathrm{C}$ in a humidified atmosphere of $5 \% \mathrm{CO}_{2}$. T20 was used as positive control. After $6 \mathrm{~h}$ incubation, the number of syncytia was scored under an inverted microscope [18].

\subsection{RT (Reverse Transcriptase) Assay}

HIV-1 RT activity was measured by ELISA RT kit (Roche) using a commercially available kit according to the protocol provided by the manufacturer. Samples were incubated with DIG-labeled-reaction mixture at $37{ }^{\circ} \mathrm{C}$ for $15 \mathrm{~h}$. Anti-DIGPOD solution was added afterward followed by substrate ABTS. The absorbance at 405/490 nm (A405/490) was determined in the ELISA reader [20].

Acknowledgements This work was supported financially by grants from the National Science Foundation of China (21432010 and 81660612) and Technological leading talent project of Yunnan (2015HA020). Yunnan Applied Basic Research Project-Kunming Medical University Union Foundation (2017FE467 (-127), Scientific Research Fund Projects from the Department of Education of Yunnan (2016ZDX042) and the HundredTalent Program of Kunming Medical University (60117190441).

\section{Compliance with Ethical Standards}

Conflict of interest These authors have no conflict of interest to declare.

Open Access This article is licensed under a Creative Commons Attribution 4.0 International License, which permits use, sharing, adaptation, distribution and reproduction in any medium or format, as long as you give appropriate credit to the original author(s) and the source, provide a link to the Creative Commons licence, and indicate if changes were made. The images or other third party material in this article are included in the article's Creative Commons licence, unless indicated otherwise in a credit line to the material. If material is not included in the article's Creative Commons licence and your intended use is not permitted by statutory regulation or exceeds the permitted use, you will need to obtain permission directly from the copyright holder. To view a copy of this licence, visit http://creativecommons.org/licenses/by/4.0/.

\section{References}

1. M. Youcef, E.D. Clercq, J. Med. Chem. 53, 521-538 (2010)

2. M.J. Marrazzo, C. Del Rio, D.R. Holtgrave, M.S. Cohen, S.C. Kalichman, K.H. Mayer, J.S. Montaner, D.P. Wheeler, R.M. Grant, B. Grinsztejn, N. Kumarasamy, S. Shoptaw, R.P. Walensky, F. Dabis, J. Sugarman, C.A. Benson, JAMA 312, 390-409 (2014)

3. M.I. Qadir, S.A. Malik, Rev. Med. Virol. 20, 23-33 (2010)

4. I.P. Singh, H.S. Bodiwala, Nat. Prod. Rep. 27, 1781-1800 (2010)

5. I.W. Park, C.R. Han, X.P. Song, L.A. Green, T. Wang, Y. Liu, C.C. Cen, X.M. Song, B. Yang, G.Y. Chen, J.J. He, BMC Compl. Altern. Med. 9, 29 (2009). https://doi.org/10.1186/1472-6882-9-29

6. Y.Y. Cheng, H. Chen, H.P. He, Y. Zhang, S.F. Li, G.H. Tang, L.L. Guo, W. Yang, F. Zhu, Y.T. Zheng, S.L. Li, X.J. Hao, Phytochemistry 96, 360-369 (2013)

7. X.J. Hao, Y.T. Zheng, H.P. He, N. Huang, C.J. Tan, C.Y. Li, Y.T. Di, R.R. Wang, China. Patent CN 102101864A (2011)

8. P.M. Allard, P. Leyssen, M.T. Martin, M. Bourjot, V. Dumontet, C. Eydoux, J.C. Guillemot, B. Canard, C. Poullain, F. Gueritte, M. Litaudon, Phytochemistry 84, 160-168 (2012)

9. M. Bourjot, P. Leyssen, J. Neyts, V. Dumontet, M. Litaudon, Molecules 19, 3617-3627 (2014)

10. S.G. Liao, H.D. Chen, J.M. Yue, Chem. Rev. 109, 1092-1140 (2009)

11. J. Lu, S.G. Deeks, R. Hoh, G. Beatty, B.A. Kuritakes, J.N. Martin, D.R. Kuritzkes, J. Acquir. Immune Defic. Syndr. 43, 60-64 (2006) 
12. P.R. Sista, T. Melby, D. Davison, L. Jin, S. Mosier, M. Mink, E.L. Nelson, R. DeMasi, N. Cammack, M.P. Salgo, T.J. Matthews, M.L. Greenberg, AIDS 18, 1787-1794 (2004)

13. X.P. Wei, J.M. Decker, H.M. Liu, Z. Zhang, R.B. Arani, J.M. Kilby, M.S. Saag, X.Y. Wu, G.M. Shaw, J.C. Kappes, Antimicrob. Agents Chemother. 46, 1896-1905 (2002)

14. L. Zhang, R.H. Luo, F. Wang, M.Y. Jiang, Z.J. Dong, L.M. Yang, Y.T. Zheng, J.K. Liu, Org. Lett. 12, 152-155 (2010)

15. L. Zhang, R.H. Luo, F. Wang, Z.J. Dong, L.M. Yang, Y.T. Zheng, J.K. Liu, Phytochemistry 71, 1879-1883 (2010)
16. A.M. Vandamme, M. Witvrou, C. Pannecouque, J. Balzarini, K.V. Laethem, J.C. Schmit, J. Desmyter, E. De, Clercq, Antiviral Methods and Protocols (Humanae Press, Clifton., 2000)

17. Y.T. Zheng, W.F. Zhang, K.L. Ben, J.H. Wang, Immunopharmacol. Immunotoxicol. 17, 69-79 (1995)

18. N. Huang, M.Y. Wu, C.B. Zheng, L. Zhu, J.H. Zhao, Y.T. Zheng, Carbohydr. Res. 380, 64-69 (2013)

19. R.R. Wang, Q. Gu, L.M. Yang, J.J. Chen, S.Y. Li, Y.T. Zheng, J. Ethnopharmacol. 105, 269-273 (2006)

20. Q. Wang, Z.H. Ding, J.K. Liu, Y.T. Zheng, Antiviral Res. 64, 189-194 (2004)

\section{Affiliations}

\section{Cheng-Jian Tan ${ }^{1,3} \cdot{\text { Shi-Fei } \mathrm{Li}^{1,4} \cdot \text { Ning Huang }^{2,5} \cdot \text { Yu Zhang }^{1} \cdot \text { Ying-Tong } \mathrm{Di}^{1} \cdot \text { Yong-Tang Zheng }}^{2} \cdot$ Xiao-Jiang Hao $^{1}$}

1 State Key Laboratory of Phytochemistry and Plant Resources in West China, Kunming Institute of Botany, Chinese Academy of Sciences, Kunming 650204, Yunnan, People's Republic of China

2 Key Laboratory of Bioactive Peptides of Yunnan Province/Key Laboratory of Animal Models and Human Disease Mechanisms of the Chinese Academy of Sciences, Center for Biosafety Mega-Science, Kunming Institute of Zoology, Chinese Academy of Sciences, Kunming 650223, Yunnan, People's Republic of China
3 School of Ethnic Medicine, Guizhou Minzu University, Guiyang 550025, Guizhou, People's Republic of China

4 Institute of Molecular Science, Shanxi University, Taiyuan 030006, Shanxi, People's Republic of China

5 School of Basic Medical, Kunming Medical University, Kunming 650500, Yunnan, People's Republic of China 